\title{
ACTUARIAL VACANCIES
}

L'Université de Lausanne cherche un

$$
\begin{gathered}
\text { Professeur de Mathématiques et } \\
\text { de Sciences Actuarielles }
\end{gathered}
$$

pour un poste à plein temps. L'enseignement consiste en un cours de mathématiques destiné aux étudiants en sciences économiques et en cours actuariels spécialisés.

Conditions requises:

- être titulaire d'un doctorat

- avoir publié des travaux scientifiques

- posséder de réelles qualités pédagogiques

Entrée en fonction: le $1^{\text {er }}$ septembre 1993.

Avant de déposer leur candidature, les intéressés voudront bien demander le cahier des charges de ce poste au Professeur Olivier Blanc, Doyen de l'Ecole des H.E.C., Université de Lausanne, CH-1015 Lausanne, Suisse tél.: 0216924136 - fax 0216924146

Délai de réception de candidature: 20 septembre 1992.

Actuarial Vacancy at the University of Oslo,

Department of Statistics and Actuarial Mathematics

Institute of Mathematics

A position at the Associate Professor level is expected to become available at the Department of Statistics and Actuarial Mathematics within a few months.

The Department of Statistics and Actuarial Mathematics is responsible for all education of actuaries in Norway. The normal course of studies towards actuarial qualification is by taking a Master's degree at The Department.

The successful candidate will be responsible for teaching, supervision and research in Actuarial Mathematics. Necessary qualifications include a Ph.D. in Actuarial Mathematics or Statistics. Candidates should have a good record of research.

Current research within Actuarial Mathematics is in the fields of Credibility Theory and Aggregate Loss Distributions. Persons with other areas of specialisation will be welcome to apply. Within Statistics in general, research at The Department covers a range of interesting areas.

Potential applicants are asked to notify their interest to Professor Bjørn Sundt, Institute of Mathematics, P.O. Box 1053 Blindern, N-0316 Oslo, Norway. Please do not send formal applications now. 